Хантакова Е. Н., Паликова Т. В., Ангархаев Б. Б. Повседневные наблюдения М. Н. Хангалова в дневниковом наследии за 1902-1911 гг.

Научная статья

УДК 94(093)"1902/11"

DOI: $10.18101 / 2305-753 X-2021-4-3-12$

\title{
ПОВСЕДНЕВНЫЕ НАБЛЮДЕНИЯ М. Н. ХАНГАЛОВА В ДНЕВНИКОВОМ НАСЛЕДИИ ЗА 1902-1911 ГГ.
}

\section{(C) Хантакова Елизавета Николаевна}

доктор исторических наук, доцент, Бурятский государственный университет имени Доржи Банзарова Россия, 670000, г. Улан-Удэ, ул. Ранжурова, 6 palelizaveta@yandex.ru

\section{(C) Паликова Татьяна Вадимовна}

доктор исторических наук, профессор, Бурятский государственный университет имени Доржи Банзарова Россия, 670000, г. Улан-Удэ, ул. Ранжурова, 6 nnet2861@gmail.com

\section{(C) Ангархаев Буда Балдынович}

младший научный сотрудник, Музей истории Бурятии им. М. Н. Хангалова Россия, 670000, г. Улан-Удэ, ул. Профсоюзная, 29 bydachka95@mail.ru

\begin{abstract}
Аннотация. Статья посвящена описанию дневников выдающегося бурятского этнографа Матвея Николаевича Хангалова, которые находятся в Музее истории Бурятии, носящем его имя в Улан-Удэ. В ходе работы над источником была подтверждена его авторская принадлежность, установлена хронология создания дневников, начата систематизация и детализация периодизации коллекции дневников. Содержание дневниковых записей можно разделить на разные смысловые сюжеты: небольшие статьи, этнографические наблюдения и рисунки по истории шаманизма прибайкальских бурят, повседневность педагогов Бильчирского училища, где с 1902 г. преподавал и сам М. Н. Хангалов, конфессиональные, общественные и бытовые аспекты народной жизни и сюжеты о своей семье. В заключении авторы делают вывод о том, дневники обладают исследовательскими данными, которые позволяют представить не только этническое, религиозное, экономическое и культурное бытование прибайкальских бурят начала XX в., но и позволяют выявить нравственные, профессиональные, человеческие установки М. Н. Хангалова.
\end{abstract}

Ключевые слова: исторические источники, дневники М. Н. Хангалова, коллекция дневников, буряты, этнография Бурятии.

\section{Для цитирования}

Хантакова Е. Н., Паликова Т. В., Ангархаев Б. Б. Повседневные наблюдения М. Н. Хангалова в дневниковом наследии за 1902-1911 гг. // Вестник Бурятского государственного университета. Гуманитарные исследования Внутренней Азии. 2021. Вып. 4. С. 3-12. 
Матвей Николаевич Хангалов - этнограф, историк, преподаватель Бильчирского училища.

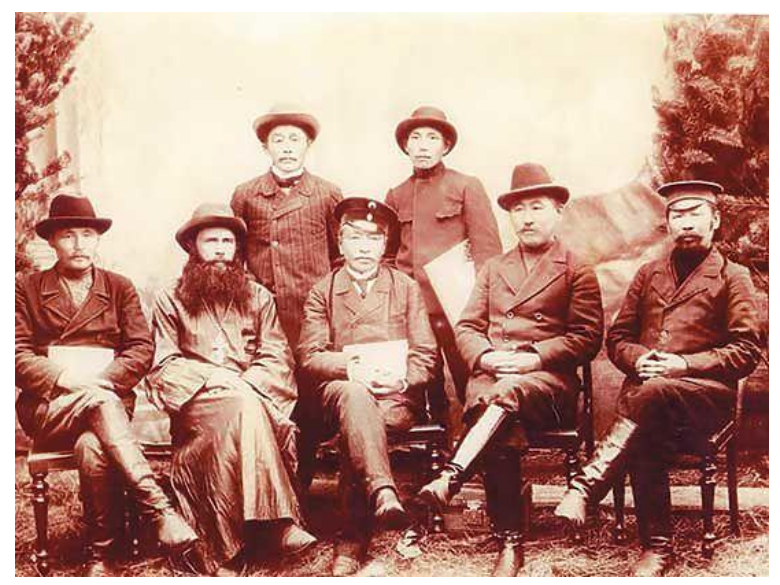

Учредители Бильчирской школь. В иентре - Матвей Хангалов ${ }^{1}$

Творческая деятельность М. Н. Хангалова до сих пор вызывает интерес исследователей. В статье авторы обратились к дневниковому наследию бурятского этнографа. Дневники за 1902-1915 гг. хранятся в музее истории Бурятии, носящем его имя в г. Улан-Удэ.

В дневниках представлены не только готовые научные статьи, в которых описаны шаманские ритуалы и обряды, но и повседневная жизнь сельского жителя Прибайкалья.

В ходе работы с дневниками была «подтверждена его авторская принадлежность, установлена хронология создания дневников, начата систематизация и детализация периодизации коллекции дневников. В процессе публикации научных статей начат ввод в научный оборот тематического комплекса исторических документов [16], а также проведена оцифровка дневников М. Н. Хангалова за 19101911 гг. с целью сохранения и дальнейшей популяризации наследия ученого» $[17 ; 18]$.

${ }^{1} \mathrm{C} 1884$ по 1890 гг. в Бильчирском ведомстве действовала православная миссионерская школа. Первое одноклассное училище со светским образованием было образовано в 1890 г. в улусе Гыртуй Бильчирского ведомства. В 1901 г. построено здание между улусами Бильчир и Наймангут (Гыртуй и Наймангут теперь входят в село Бильчир). В 1906 г. благодаря М. Н. Хангалову преобразовано в Бильчирское Николаевское двухклассное училище. В 1920 г. получило статус школы 1 ступени. С 1930 г. - школа крестьянской молодежи. С 1936 г. - неполная средняя школа. В 1949 г. стала Бильчирской средней школой. Бильчирская школа — альма-матер трех долин. URL: https://asiarussia.ru/ articles/9286/ (дата обращения 10.11.2021). 
Хантакова Е. Н., Паликова Т. В., Ангархаев Б. Б. Повседневные наблюдения М. Н. Хангалова в дневниковом наследии за 1902-1911 гг.

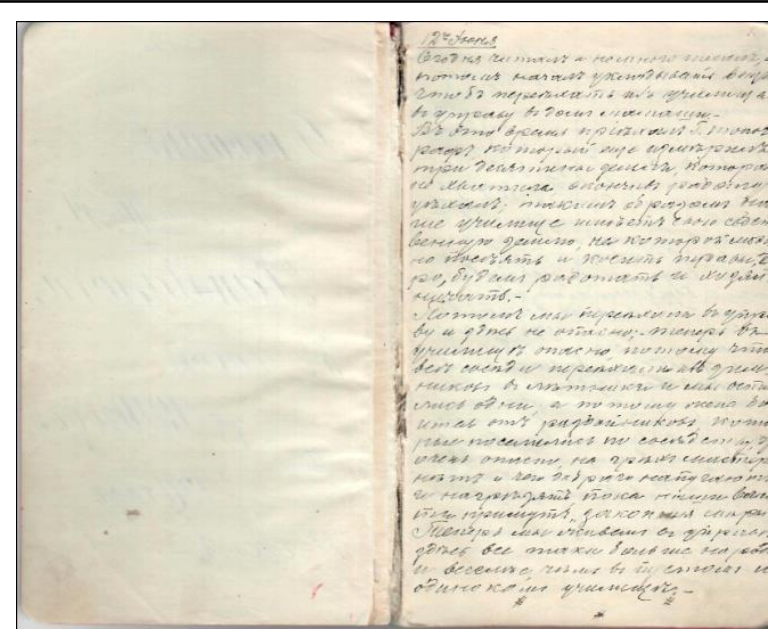

Дневники М. Н. Хангалова

Описание каждого дня исследователь начинает с указания числа, планов на предстоящий день и заканчивает дневниковую запись «так кончился день. 一». В дневниках представлены наблюдения-исследования: описания проведения шаманских обрядов Иркутских прибайкальских бурят, школьной повседневности преподавателей Бильчирского училища, где с 1902 г. руководил и преподавал и сам М. Н. Хангалов, православных, общественных и бытовых аспектов народной жизни и семейных сюжетов.

Приведем некоторые расшифровки записей. Так, при описании шаманских обрядов встречается описание шаманских принадлежностей, например, изображение змей: «Змеи на шаманских принадлежностях и одеяниях встречаются часто и в историческом отночении имеет важное символическое значение, как другия животныя звери, птицыл, рыбы и проч.

На шаманских мяхабши на самой верхушке на месте рог или птии встречается железное изображение змеи, как символ шаманского произхождения. На шаманских оргоях изображение змеи встречаются много. На шаманских оргоях изображениях змеи делают из железа или из разных материй черных, бельх, пестрых, желтых и красных и из разных ремней, которые бывают в большом числе» ${ }^{1}[15$, л. 46]. Далее автор поясняет, что змеи на шаманских ритуальных принадлежностях имеют важное символическое значение, так как «покровительствуюшие Заяны ездят на громадных змеях «Абарга», которая служит ездою и иногда посланником, толстыя змеи служат поясами и тонкия змеи тоже служат кушаками» [15, л. 47]. «Буряты, живущчие по Якутскому тракту, Якутского и Верхоленского уездов делают отдельные религиозные [обряды] змеиному царю, которого называют Алтан-Тали, который живет [15, л. 48] на горе Байтаг в Верхне Кудинском ведомстве Верхоленского уезда. 一».

Далее автор дневников объясняет, что символ змеи часто упоминается не только в шаманских призываниях, но в сказках, легендах, приданиях: «В бурят-

\footnotetext{
1 Здесь и далее сохранены стиль, орфография и пунктуация оригинала.
} 
ских сказках и преданиях упоминается мого-хан по русски Змея-иарь, которая длины несколько десятков сажени, громадной толщины и на лбу имеет один рог. Змея-иарь имеет громадную физическую силу, превращений и таинственная силы, с помощью которых все делает: бедного человека делает богачом и мертваго человека воскресает и т. д. Эти змеи-иари бывают добрые - белые и худыя черныля и красныяя».

В заключении М. Н. Хангалов делает вывод, что «одним словом змеи в бурятской мифологии имеет важное историческое значение» [15, л. 48].

Практически все обряды прибайкальских шаманов производятся с использованием спиртных напитков (тарасуна, вина): «[к] предварительнымм религиознымм обрядам, которых по старинному шаманскому обычаю не обходимо сделать перед посвящением на шаманский сан от шамана Эмэ, который в это время сидел на севереной стороне очага огня, перед ним в посуде стоял тарасун, которого брызгал местным горным стариам один местный старик; когда старик окончил, тогда тарасун выпили старики. —» [15, л. 68]. Бывало, излишнее употребление алкогольных напитков приводило к комическим сюжетам, что хорошо показано в описании обряда посвящения в шаманы.

При описание многодневного шаманского обряда посвящения в шаманы, где привлекается достаточно много людей как непосредственно участников обряда, так и зрителей-верующих, Хангалов сначала фиксирует диалог между главными участниками обряда:

«Оба шамана обратились к 3 сыновьям, от которых просили: будут шаманuть?

3 сыновья ответили: будем!

Потом оба шаманы спросили будите ли пить тарасун?

Сыновья ответили: не будем!

Потом оба шамана спросили будите ли ругаться и драться?

3 сыновья ответили: не будем!

Потом оба шамана спросили: будите ли нести знамя чисто?

3 сыновья ответили: будем!» [15, л. 76], затем продолжает его описание: «После этого оба шаманы на старшего сына надели по старинному обычаю белую меткалевую шапку и на всех троих привязали белые и синие меткалевые лентыл.

Потом одного выбранного старика кузнеца посадили, на него тоже надели белую шапку и перед ним поставили в посуде тарасун и красную деревянную чашку; этот старик по старинному обычаю называется «Х̈̈̈нгии»-обогон или Х̈̈̈нгин-Ноён, который медленно пил тарасун с другими стариками, которые поместились около его. - Потом вновь посвящаемый шаман Эмэ на отиа шамана надевал белую меткалевую рубачку и шапку; а сам тоже надел такую же белуюру башку и шапку; в это время обоим шаманам дали верховые кнуты, на которых были привязаны колокольчики с белыми и синими меткалевыми лентами; этих кнутов оба шамана держали в руках, как символ власти. 一». Далее автор дневников дает подробное описание обряда на протяжении нескольких дней.

Матвей Николаевич приходит к выводу, что с одной стороны, старшее поколение с уважением относилось к шаманским традициям, а с другой, что молодежь, задача которой усвоить и стать продолжателями традиций уже относилась с долей недоверия к подобного рода ритуалам и участвовала в них номинально и, 
Хантакова Е. Н., Паликова Т. В., Ангархаев Б. Б. Повседневные наблюдения М. Н. Хангалова в дневниковом наследии за 1902-1911 гг.

скорее всего, это было вынужденным шагом, демонстрирующим лишь уважение к «отцам». Такое отношение молодого поколения выражалось в несерьезном отношении к проведению самого обряда.

«30-го июня. Сегодня утром я встал рано не много писал; а потом отправился в летник шамана Эмэ, который сегодня должен делать главные религиозные обряды шаманского посвящения и будет посвящаться на шаманский сан и сделается настоящим шаманом. Когда я пришел [к] шаману Эмэ, которого я достал [в]очень печальном и стревоженном состоянии, потому что с ним случилось не приятные приключение. Вчера они во время старинного обычая «юмагиклха» ночью возвратились домой только вновь посвященныий шаман Эмэ с младшим сыном и прочие потерялись: отиа шамана не было неизвестно где он отстал от них и остался ночевать и кричать того старшего и среднего сыновей также не было с туками т. е. со знаменами. Туг старшего сына нашли на дороге в зимниках Бильчирского улуса, а средняго сына с тугом совсем не было. Местные старики были стревожены и печальны; они говорили, что это большой грех недобро.

Около 10 утра приехал отец шаман, который ночевал в НижнеНаймангутском улусе; а средняго сына с тугом не могли найти, местные старики удивлялись и серьезно толковали, куда они могли уехать в пьяном виде. -

Когда отеи шаман приехал, тогда между обоими шаманами произошло не приятное объяснение: шаман Эмэ говорил убежденно и старался доказать, что это не допустимый грех, что два сына потеряли знамена, которых могут обнюхать собаки или же разорвать часть зверинных шкурок, за такое оскорбление и за грех Заяны могут разгневаться на них и присудить их к болезни и смерти. Местные старики утешали их, что Заяны милостивы и простят грехи двух сыновей. - Корме того вчера шаман Эмэ во время быстрой езды в пьяном виде, ударился грудью об конеи драньи и упал к ногам коня, который его лягнул в грудь; все это производило не приятное и удручающее впечатление вновь посвящзаемый шаман Эмэ был сильно печален, по временам раздражителен, что на стариков производило не приятное [в]печатление, они были [в]не особенно хорошем расположении духа, постоянно спорили и ссорились. -

В это тяжелое время явился средний сын без знамени, которого он не смогли найти; он спал в зимнике, ничего не помнит, где и как потерял знамя; - старики совсем утихли и смотрели печально. Потом оба шамана молча и грустно начали приготовляться к религиозным обрядам. С самого утра приезжали буряты с разных улусов с тарасуном и привозили подарки [в]овеи; сегодня привезли 15 баранов и 2 козла; привезенное вино брызгали, которое продолжалось поти без прирывно; старики и гости пили тарасун. -

В это самое время закололи одного барана, мясо и внутренность которого сварили и положили в корзины, чтобы было готово. —» [15, л. 85-87].

Обращает на себя внимание, что, хотя сам исследователь и открыто не выказывает осуждения, но религиозное пьянство становится лейтмотивом в этнографических зарисовках. Из отрывка понятно, что опьянение привело к печальным результатам, которые с точки зрения шаманов и стариков могли привести к нерадостным последствиям. Тяжесть сложившейся ситуации заключалась в том, что с точки зрения шаманизма, подобное квалифицировалось как грех, а за «грех 
Заяны могут разгневаться на них и присудить их к болезни и смерти». Интересна реакция стариков - участников и наблюдателей в этой ситуации, которые достаточно лояльно отнеслись к поступкам молодого поколения: «утешали $u x$, что Заяны милостивы и простят грехи двух сыновей».

Любопытны описания бытовых аспектов жизни прибайкальцев-селян, фиксирующихся на уровне устойчивых слухов, которые автором в дневниках обрисованы весьма эмоционально:

«27-го июня. Сегодня встал рано и принялся за чтение; - семейство спит. После чая я думал писать т.е. вчерачную работу окончить; но пошли слухи, что нашего письмоводителя толстяка сменили и назначили суглан для выборов нового головы. Да, будет большая перемена в нашей обыденной жизни. По слухам, на место толстяка назначен письмоводителем тоненький Веретейников, который в пьяном виде побил свою жену, вытачил на улииу, облил ее керосином и сжег, как стог сено или соломы; не счастная жена сгорела т. е. получила сильные обжоги и сгорели волоса, потому что облитое керосином платье моментально спыхнуло; пока обливали водою и не торопясь обдирали горевще[е] платье, на теле не осталось не сгоревшего места; вид был страшный, но не смотря на это она была жива несколько часов и умерла в страшных муках. -

По местным слухам и сплетням причиною ссоры была местная поподья вдова, на которой после Веретийников женился по любви. -

Веретийникова русский суд оправдал и в некотором отношении даже поблагодарил за его предусмотрительность и за сбережение общественного добра, потому что Веретийников, как письмоводитель жил при управе в общественной квартире; если он жену облил керосином, сжег, то смогла бы сгореть управа и квартира и жена его и сказали бы что пьяная жена уронила огонь, потому что она пила сильно. Тут только одна жена сгорела. У русского суда еще культурное око не от крылось. - Теперь разговоров много есть и о чем поговорить ... Один бурят и один купеи сказали, что Веретейников у нас служил прежде - на право и на лево не смотрит, а только вперед смотрит, чтобы не упасть в яму; Ну, как все письмоводители. А другой бурят сказал, что [к] нашему берегу пристают все не желательное» [15, л. 62-64].

Однозначна позиция автора, не скрывающего негативного отношения к православной миссионерской деятельности: «1-е октября. Утром я поехал в церковь, в которой народу было не особенно много. От ... заимок...крестьяне со своими женами и дочерьми; из бурят был только один. - странно, в прежнее время в Покров бывало? В иерквях много бурят, а ныне совсем не заглядывают в иерковь, которую избегают. - Мне, кажется, что главная причина такого отношения, - ... невежественный и пьяный поп, который довел дело до того, что буряты перестали ходить в иерковь. Конечно, виною к этому не буряты, а сами русские попы, которые поставили дело так, что вооружили против себя бурят, [к] которым относятся [c] ненавистью и презрением, - вследствие их безвестных? ... в материальном отношении. - Ныне положение наших поповмиссионеров не завидны; теперь за их плечами не стоит полиция со своими каталажками и тюрьмами и-и- итыками без которых они безсильны и ничтожны. -

Теперь оказывается все наши попики озлоблены против бурят, которыми недовольны, что у них прекратились все доходы, потому что буряты перестали венчаться в белом. И платить попам безумные деньги, да - бывали примеры 
Хантакова Е. Н., Паликова Т. В., Ангархаев Б. Б. Повседневные наблюдения М. Н. Хангалова в дневниковом наследии за 1902-1911 гг.

платили до 300 руб. — по состоянию. А главное - после покойников ныне не дают коней, которых в прежние года собирали десятками. - [15, л. 164].

Все изменилось! Попы пали духом и уныло смотрят на жизнь и будущее. Не все коту масленица и настанет великий пост. -

Наши попы миссионеры не думали, что будут такие времена и все перемениться в жсизни народа; на бурят не обращали внимание, а только надеялись на полииию, которая всегда выручала их и помогала во всем» [15, л. 160]. В этой записи чувствуется одновременно и эмоционально-негативное отношение автора к миссионерам и боль за свой народ.

Другая запись на схожую тему констатирует факт неприятия православия не только бурятами, но и русскими. «26-го ноября. Сегодня наш сибирский и местный праздник Св. Иннокентия Иркутскаго; я поехал в иерковь, в которой было холодно и молящихся совсем мало: около 15 учеников-бурят, которых пригнали учителя, 4 учителя-буряты, одна женщина из заимки, местные торговки, один крестьянин, который живет в работниках, только; [в] прежнее время на этот праздник приезжали буряты от разных улусов, а ныне перестали и русские, совсем мало ходят. Наши миссионеры скоро доведут до того, что буряты совсем перестанут ходить в иерковь; - необходимо миссионеров обновить свежими и не отсталыми силами, чтобы они не обижали бурят, а относились бы [к] им гуманно и мягко; - Этим путем только могут поправить дела миссии, а не силой и руганьем, как ныне делают. Наши миссионеры люди отсталые, невежественные, они хотят по-прежнему эксплоатировать бурят в материальном отночении» [15, л. 223].

Вызывают интерес дневниковые записи о школьной повседневности. Следующий отрывок, например, отображает отношение Хангалова к национальным кадрам: «Сегодня законоучитель не был на уроки, и говорили, что он уехал в Улейское ведомство, [c] собою увез нового учителя, который назначен учителем для Улейской иерковно-приходской школы. Новый учитель из бурят Ильин. Очень отрадно, что учителя из бурят с каждым днем умножаются и умножаются и начинают вытеснять учителей русских, которые плохие работники в бурятских училищах; они детей не понимают, а дети их не понимают и только мучаются. Уроки кончились благополучно» [15, л. 114].

На страницах дневника М. Н. Хангалов предстает перед читателем как собиратель коллекции обрядовых артефактов: «Когда пришли в зимник, тогда бурят Хэдэгэнэ отворил амбар и указал [на] онгоны; - мы с тарасуном сделали религиозный обряд «духаху» и выпили. - Я ему отдал деньги, вомел в амбар и взял онгонов, которые все были в деревянных ящиках; я их понес в училище и положил амбар, в котором я держу все собранные коллекиии до отправки в музеи. 一 $[15$, л. 114]. «В Бильчирском улусе были куплены «онгоныл», «хозяин зурака на длинной палочке» за 1 р. 50 к.» [15, л. 10], «старинныя посвященныя стрелы» «с лентами, мешечками с хлебными зернами, монетами и пуговицами за 50 коп.» [15, л. 13], «белую меткалевую рубашку и шапку» [15, л. 113]. Хотелось бы отметить, шаманские артефакты М. Н. Хангалов приобретал на собственные деньги, (жалование преподавателя было в описываемое время было скудное). Данный факт характеризует Хангалова как настоящего профессионала. Собранные артефакты в дальнейшем пополнили коллекции различных музеев и научных центров («Я om 
вез в музей [ВСОИРГО - Авт.], все привезенныя шаманския коллекции разных онгонов, ... зураков, шаманских тростей, зулу и много прочих») [15, л. 141].

Наконец, записи в дневнике демонстрируют уровень образования его автора (Казанский университет), такт и уважение к своему народу, которому Матвей Николаевич посвятил свою жизнь. Служение бурятскому народу на просвещенческом и исследовательском поприще, по заслугам было оценено современниками и потомками, а последующие поколения ученых отдали дань уважения подвижнической деятельности исследователя по сбору и описанию этнографических коллекций, традиций, обрядов и обычаев бурят опубликовав его научные труды в трехтомном издании 1958 г. и переиздав в 2004 г. [13].

Дневниковые записки М. Н. Хангалова свидетельствуют о нем не только как о профессиональном исследователе, но и о неравнодушном к благоприятному будущему человека - патриота своего народа.

Это лишь немногие отрывки из 150-страничного дневника, отразившие его основные темы. Работа над историческим наследием Матвея Николаевича Хангалова продолжается.

Лuтература

1. Залкинд Е. М. М. Н. Хангалов. Улан-Удэ: Бурмонгиз, 1945. 63 с. Текст: непосредственный.

2. Залкинд Е. М., Хаптаев П. Т. М. Н. Хангалов. Улан-Удэ: Бурят. кн. изд-во, 1983. 116 с. Текст: непосредственный.

3. Хамаганов М. П. М. Н. Хангалов как этнограф-фольклорист (1858-1918) // Советская этнография. 1959. № 5. С. 98-108. Текст: непосредственный.

4. Андреев В. И. Хангалов как учитель и деятель просвещения // Выдающиеся учителя и просветители Бурятии. Улан-Удэ, 1961. С. 72-92. Текст: непосредственный.

5. Мантатов В. В., Болотов Х. Д. К вопросу о мировоззрении М. Н. Хангалова: этнограф-фольклорист. 1858-1918 // Современность и традиционная культура народов Бурятии. Улан-Удэ, 1983. С. 129-140. Текст: непосредственный.

6. Тугутов И. Ученый с мировым именем: к 135-летию со дня рождения М. Н. Хангалова // Знамя Ленина. 1993. 25 ноября. Текст: непосредственный.

7. Дамбуева И. А. Творческое наследие М. Н. Хангалова в архивных фондах гг. Иркутска и Улан-Удэ // Вестник Иркутского государственного технического университета. № 1. 2004. С. 190-193. Текст: непосредственный.

8. Жамбалова С. Г. Матвей Николаевич Хангалов - этнограф, ученый мирового значения // Хангаловские чтения: материалы межрегиональной научно-практической конференции (24 октября 2008 г.). Усть-Ордынск, 2008. С. 6-9. Текст: непосредственный.

9. Жамбалова С. Г. О жизни и деятельности М. Н. Хангалова: известные и малоизвестные факты // Этническая история и культурно-бытовые традиции народов Байкальского региона. Иркутск: Оттиск, 2010. С. 6-20. Текст: непосредственный.

10. Маласханова И. А. Научное сотрудничество М. Н. Хангалова с деятелями ВСОРГО // Гуманитарный вектор. 2012. № 2(30). С. 148-153. Текст: непосредственный.

11. Михайлова В. Т. Неопубликованные дневники М. Н. Хангалова, 1902-1915 гг. // Хангаловские чтения: материалы межрегиональной научно-практической конференции (24 октября 2008 г.). Усть-Ордынск, 2008. С. 9-20. Текст: непосредственный.

12. Жукова Н. Е., Ангархаев Б. Б. Научное наследие Матвея Николаевича Хангалова в трудах ученых Байкальского региона // Вестник Бурятского государственного университета. Гуманитарные исследования Внутренней Азии. 2020. № 1. С. 43-50. Текст: непосредственный. 

в дневниковом наследии за 1902-1911 гг.

13. Хангалов М. Н. Собрание сочинений: в 3-х т. / под ред. Г. Н. Румянцева. УланУдэ: Бурят. кн. изд-во, 1958-1961. Текст: непосредственный.

14. Жамбалова С. Г. Предисловие // Хангалов М. Н. Собрание сочинений: в 3-х т. / под редакцией Г. Н. Румянцева. Улан-Удэ: Изд-во ОАО «Республ. тип.», 2004. С. 10-14. Текст: непосредственный.

15. МИБ (Музей истории Бурятии). ОФ-4136. Дневник № 11, 2-я часть за 1910 г. М. Н. Хангалова. Записи личные с апреля по июнь 1910 г. с. Бильчир Иркутской губернии, 1910 г.; МИБ. ОФ-4137. Дневник № 12, 3-я часть за 1910-1911 гг. М. Н. Хангалова. Записи личные с июня 1910 г. по ноябрь 1911 г. с. Бильчир Иркутской губернии, 19101911 гг. 657 л.

16. Палхаева Е. Н., Жукова Н. Е., Паликова Т. В. «Школьная» повседневность начала XX века: по материалам дневников М. Н. Хангалова // Ученые записки Забайкальского государственного университета. 2020. Т. 15. № 5. С. 79-86. Текст: непосредственный.

17. Палхаева Е. Н., Паликова Т. В., Митупов К. Б.-М., Ангархаев Б. Б. Дневники Хангалова М. Н. - ценный исторический источник по изучению истории прибайкальских бурят начала XX в. // Проблемы социально-экономического развития Сибири. 2021. № 3. С. 125-130. Текст: непосредственный.

18. Жукова Н. Е., Палхаева Е. Н., Паликова Т. В. «...Учителя или учительницы занимаются охотно и не жалуются»: этнограф М. Н. Хангалов на службе у просвещения // Вестник Бурятского государственного университета. Гуманитарные исследования Внутренней Азии. 2021. Вып. 2. С. 20-27. Текст: непосредственный.

Статья поступила в редакцию 12.11.2021; одобрена после рецензирования 03.12.2021; принята к публикации 17.12.2021.

\section{EVERYDAY OBSERVATIONS OF M. N. KHANGALOV \\ IN THE DIARY HERITAGE FOR 1902-1911}

\section{Elizaveta N. Khantakova}

Dr. Sci. (History), A/Prof. of World and Russian History Department,

Dorzhi Banzarov Buryat State University

6 Ranzhurova St., Ulan-Ude 670000, Russia

palelizaveta@yandex.ru

Tatyana V. Palikova

Dr. Sci. (History), Prof. of World and Russian History Department,

Dorzhi Banzarov Buryat State University

6 Ranzhurova St., Ulan-Ude 670000, Russia

nnet2861@gmail.com

Buda B. Angarkhaev

Researcher,

Muzeum of the History of Buryatia named after M. N. Khangalov

29 Profsouznay St., Ulan-Ude 670000, Russia

bydachka95@mail.ru

Abstract. The article is devoted to the description of the diaries of the outstanding Buryat ethnographer Matvey Nikolaevich Khangalov, which are located in the Museum of the History of Buryatia, bearing his name in Ulan-Ude. During the work on the source, its au- 
thorship was confirmed, the chronology of the creation of diaries was established, the systematization and detailing of the periodization of the collection of diaries began. The content of the diary entries can be divided into different semantic plots: small articles, ethnographic observations and drawings on the history of shamanism of the Baikal Buryats, the daily life of the teachers of the Bilchir School, where M. N. Khangalov himself taught since 1902, confessional, social and everyday aspects of folk life and stories about his family. In conclusion, the authors conclude that the diaries have research data that allow us to present not only the ethnic, religious, economic and cultural existence of the Baikal Buryats of the early twentieth century, but also allow us to identify moral, professional, human.

Keywords: historical sources, diaries of M. N. Khangalov, collection of diaries, Buryats, ethnography of Buryatia.

\section{For citation}

Khantakova E. N., Palikova T. V., Angarkhaev B. B. Everyday Observations of M. N. Khangalov in the Diary Heritage for 1902-1911. Bulletin of Buryat State University. Humanities Research of Inner Asia. 2021; 4: 3-12 (In Russ.).

The article was submitted 12.11.2021; approved after reviewing 03.12.2021; accepted for publication 17.12.2021. 